\title{
Intergenerational Solidarity and Satisfaction With Life: Mediation Effects With Emerging Adults
}

\author{
Susana Coimbra ${ }^{1}$ \\ Universidade do Porto, Porto, Portugal \\ Marina Goulart Mendonça \\ Keele University, Staffordshare, United Kingdom
}

\begin{abstract}
The increasing dependency of emerging adults (EA) on their family of origin and their lower future expectations challenge intergenerational family support exchanges and may affect their impact on satisfaction with life. This study aims to examine the mediation effect of familism, filial maturity, and relationship satisfaction between different directions of support (received, given and anticipated between both) and satisfaction with life. Data was collected through the administration of self-report questionnaires to a convenience sample of 243 EA (18-30 years old) of both genders, students and workers, of different socioeconomic statuses. Results corroborate the mediation effect of the study variables and suggest that the magnitude of this impact depends on the direction of the support: partial mediations are observed for the received support, whereas total mediations are observed for the given support.
\end{abstract}

Keywords: solidarity, intergenerational relations, subjective well-being

\section{Solidariedade Intergeracional e Satisfação com a Vida: Efeitos de Mediação com Adultos Emergentes}

\begin{abstract}
Resumo: A crescente dependência dos adultos emergentes em relação à sua família e as suas menores expectativas em relação ao futuro desafiam as trocas de solidariedade entre gerações e podem afetar a satisfação com a vida. Este estudo teve por objetivo avaliar o efeito mediador do familismo, maturidade filial e satisfação com a relação na associação entre diferentes direções de apoio (recebido, dado e discrepância entre ambos) e a satisfação com a vida. Foram utilizados questionários de autorresposta em uma amostra de conveniência de 243 adultos emergentes de ambos os sexos, estudantes, trabalhadores e pertencentes a diferentes níveis socioeconômicos. Os resultados corroboram o efeito mediador das variáveis em estudo e sugerem que a magnitude do seu impacto depende da direção do apoio: são observadas mediações parciais para o apoio recebido e mediações totais para o apoio dado.
\end{abstract}

Palavras-chave: solidariedade, relações entre gerações, bem-estar subjetivo

\section{Solidaridad Intergeneracional y Satisfacción con la Vida: Efectos de Mediación con Adultos Emergentes}

\begin{abstract}
Resumen: La creciente dependencia de los adultos emergentes (AE) con respecto a su familia y sus menores expectativas sobre el futuro desafían el intercambio de solidaridad entre las generaciones y pueden influir en su impacto sobre la satisfacción con la vida. Este estudio tiene como objetivo evaluar el efecto mediador del familismo, de la madurez filial y de la satisfacción con la relación entre diferentes direcciones de apoyo (recibido, dado y discrepancia entre ambos) y la satisfacción con la vida. Los datos fueron recogidos mediante la administración de cuestionarios de auto-respuesta a una muestra de conveniencia de $243 \mathrm{AE}$ de ambos sexos, estudiantes y trabajadores, pertenecientes a diferentes niveles socioeconómicos. Los resultados apoyan el efecto mediador de las variables estudiadas y sugieren que la magnitud de su impacto depende de la dirección del apoyo: se observan mediaciones parciales por el apoyo recibido y mediaciones totales por el apoyo dado.
\end{abstract}

Palabras clave: solidaridad, relaciones entre generaciones, bienestar subjetivo

One of the main consequences of the increased longevity and reduced birth rates observed in recent decades in Western societies is a strong disequilibrium between those supporting (active population) and those benefitting

\footnotetext{
Support: This work is funded by FEDER funds through the Operational Program Competitiveness Factors - COMPETE and by National Funds through FCT - Foundation for Science and Technology in the project FCOMP-01-0124-FEDER-022714.

2 Correspondence address:

Susana Coimbra. Faculdade de Psicologia e de Ciências da Educação da Universidade do Porto, Rua Alfredo Allen, 4200-135, Porto, Portugal.

E-mail: susana@fpce.up.pt
}

(inactive population) from the social security system. The ongoing global financial crisis can enhance the competition for scarce resources and services between generations even further, and even end up questioning the social contract between generations (Yarrow, 2009). The impact of these social and demographic changes gains particular outlines according to different countries' values and resources (Haberkern \& Szydlik, 2010). It seems to extend to different cultures through globalization though, and is present in the generalization of new family structures (Arriagada, 2000). Intergenerational solidarity, whether in the strict family sense or in the broader societal context, is increasingly interesting today 
when compared to previous generations (Bengtson \& Oyama, 2010; Lowenstein, 2010).

In a scenario in which the stability of careers and romantic relations is decreasing, intergenerational family support gains importance for young people's survival and wellbeing. At the same time, the exchanges among members of different generations probably are more and more asymmetric and unbalanced too. The parents' investment, who tend to be members of the sandwich generation, is increasingly comprehensive, with little probability of getting any return, going against the previews of the so-called "solidarity bank" effect (Antonucci, 1985; Grundy \& Henretta, 2006; Lennartsson, Silverstein, \& Fritzell, 2010).

The transition to adult life does occur increasingly late in developed societies in general (Arnett, 2004; Brandão, Saraiva, \& Matos, 2012; Jensen \& Arnett, 2012), as young people are able to achieve the markers that are traditionally associated with this transition later and later - graduating, getting a job, experiencing marital life and parenthood. Consequently, young people's greater and longer dependence on their family of origin is observed, in financial, functional, emotional and even residential (cohabitation) terms, particularly in Southern European countries (Andrade, 2010; Mendonça \& Fontaine, 2013a). In those countries, including Portugal, the transition to adult life is seen as a "joint developmental enterprise" (Scabini, Marta, \& Lanz, 2006), as both generations are actively involved in this process. Some reasons can be indicated, including economic conditions (difficult job market and greater gap between socioeconomic groups), structural characteristics (lack of social security policies/public welfare policies, replaced by the so-called "family welfare state") and cultural values (higher rates of familism) (Da Roit, 2007; Fontaine, Andrade, Matias, Gato, \& Mendonça, 2006; Guerreiro \& Abrantes, 2004; Haberkern \& Szydlik, 2010).

Auto-focus is an important characteristics of the developmental phase of emerging adulthood (Arnett, 2004). In addition, recent studies have also evidenced that this is a distinctive characteristic of the new generation. The observed increase in agentic and self-centered traits like narcissism or self-esteem (Gentile, Twenge, \& Campbell, 2010; Twenge \& Campbell, 2009) and the decreased interest in social and public causes (like civic orientation) truly justify the proposed term generation me (Twenge, Campbell, \& Freeman, 2012). Although emerging adults and/or members of the generation $m e$ are not described as selfish or spoiled (Arnett, 2007; Twenge, 2006), it seems probable that their characteristics, strongly marked by the individualistic ideology as an appeal to personal accomplishment (Lago, Souza, Kaszubowski, \& Soares, 2009), can compromise their current help behaviors and their intentions to give help in the future. Particularly when, for the first time in recent history, no improvement in living conditions is expected for the younger generation when compared to their parents' generation (Chauvel, 2006; Coimbra, Ribeiro, \& Fontaine, 2013; Yarrow, 2009).
Intergenerational family solidarity is an open, fluid and multidimensional taxonomy, which has been widely tested in different societies and describes the interactions among generations, particularly between parents and adult children, in the course of the lifecycle (Hogerbrugge \& Komter, 2012). It relates to behaviors, but also to attitudes, values, emotions and feelings of belonging, which can be grouped in two main dimensions: structural-behavioral and affective-cognitive (Lowenstein, 2007).

The first, structural-behavioral dimension includes geographic proximity (structural solidarity), the frequency of shared activities (associative solidarity) and functional solidarity. The latter refers to exchanges of support and resources, such as domestic chores, transportation and shopping, information and advice, financial support, emotional support, decision making, help in case of illness and assistance with personal care (Lowenstein, 2007; Silverstein \& Bengtson, 1994; Szydlik, 2008). The second, affective-cognitive dimension relates to the sharing of beliefs, values and attitudes (consensual solidarity) and commitment with regard to the performance of family roles and obligations (normative solidarity). It also includes reference to positive feelings towards family members (affective solidarity), which can be expressed in terms of relationship quality (Lowenstein, 2007; Silverstein \& Bengtson, 1994; Szydlik, 2008).

Family solidarity seems to enhance wellbeing, although no consensus exists on the empirical results with regard to this relationship (Merz, Schulze, \& Schuengel, 2010; Silverstein \& Bengtson, 1994; Silverstein, Chen, \& Heller, 1996). It has been suggested that it depends on the predominant values in society and most studies are focused on the impact of help recipients (Katz, 2009; Schwarz et al., 2010). It has been assumed that being a help recipient increases wellbeing, while being a provider can constitute a burden, further anxiety and depression and, therefore, reduce wellbeing (Rezende et al., 2010). Receiving help, however, can be perceived as a sign of loss of physical and financial autonomy by the ageing parents (Merz et al., 2010). In this context, being a help recipient may also reduce wellbeing. Similarly, in emerging adults, the support received from their parents can also be perceived as a sign of lack of maturity and autonomy (Aquilino, 2006). This is common practice nowadays though, particularly in more familist countries. Therefore, it is easy to understand that the impact of giving or receiving help on wellbeing is neither uniform nor linear, but mediated by variables like cultural values and prevailing norms (Schwarz et al., 2010). On the other hand, it has also been observed that help providers often experience happiness and personal accomplishment, perceiving intergenerational solidarity as an opportunity to repay the help received in earlier life phases (Merz et al., 2010). Hence, it is expected that anticipating the ability to repay parental investment in terms of time, money and care will affect emerging adults' satisfaction with life.

The filial maturity construct gains particular relevance in this context. Filial maturity seems to be an important variable 
to prepare adult children for the normative task of taking care of their parents at the end of life (Brody, 1985; Marcoen, 1995). Although normative, this task is not free from possible tensions between the needs for independence and dependence, between the help adult children can and want to give and the help the parents expect and want to receive. Filial maturity relates to adult children's capacity to interact with their parents in a reciprocal relationship, perceiving them as people who exist beyond the father/mother-son/daughter relationships, understanding their limitations, personal history and needs for help (Birditt, Fingerman, Lefkowitz, \& Dush, 2008; Marcoen, 1995). Hence, it implies the development of a more intimate, comprehensive, symmetric and reciprocal father/mother-son/ daughter relationship, which is why it was also included as a mediating variable in this research.

This study was aimed at assessing the mediator effect of familism, filial maturity and satisfaction with the relationship in the association between different support directions (received, given and the discrepancy between both) and satisfaction with life. It is assumed that both receiving and giving support, on the one hand, and the perception of more balanced exchanges between generations (emerging adults and their parents), on the other, enhance satisfaction with life. It is also expected that the effect of the support received, the support given and the discrepancy on satisfaction with life is mediated by normative values (familism), by the development level (filial maturity) and by the bonds of affections (quality of the relationship).

\section{Method}

\section{Participants}

The study participants were 243 emerging adults between 18 and 30 years of age $(M=20.77 ; S D=3.346 ; M o=18)$. Most of the sample consisted of women (58\%), college students $(72.8 \%)$ and single individuals (95.9\%). It was verified that $68.7 \%$ of the participants lived with at least one of their parents. In the other cases, they lived with friends/colleagues $(12.3 \%)$, alone $(9.6 \%)$, with boy-/girlfriends or partners $(8.4 \%)$ or in other shared housing solutions (with other relatives for example). The socioeconomic levels of the original family (assessed based on the father and mother's profession and educational level) that were most present in the sample were medium-low (30.5\%) and low (26.3\%). The professions were assessed according to Graffar's classification. The highest frequencies were found for unqualified, semi-qualified or qualified workers, small retailers or owners. The educational level of most participants' parents $(57.6 \%)$ was equal to or inferior to compulsory education ( $3^{\text {rd }}$ cycle of Basic Education in Portugal or Primary Education in Brazil).

\section{Instruments}

The support the emerging adults received from, gave and anticipated to their parents was assessed by Bengtson and Roberts' Index of Intergenerational Solidarity (1991), adapted by Monteiro (2010). In the present study, the internal consistency scores for the three functional solidarity versions were high: .86 for the support received from parents, .85 for the support given to parents and 93 for the support they anticipate to give to their parents.

Subjective well-being was assessed using the Satisfaction With Life Scale by Diener, Emmons, Larsen and Griffin (1985), adapted by Neto, Barros and Barros (1990), with an internal consistency coefficient equal to .81. The familism dimension of Fontaine and Matias' (2003) Escala de Individualismo e Familismo (Individualism and Familism Scale) was used to measure normative solidarity, with an internal consistency coefficient of .81. Filial maturity was assessed using the comprehension subscale of the Filial Maturity Scale by Birditt et al. (2008), adapted by Mendonça and Fontaine (2013b), with an internal consistency coefficient of .84 . Finally, to measure satisfaction with the relationship with parents, the Network of Relationship Inventory by Furman and Buhrmester (1985) adapted by Oliveira (2011) was applied, with an internal consistency coefficient of .87 .

\section{Procedure}

Data collection. The data were collected collectively among the group of college students of different courses attending the University of Porto, coming from different courses. Data from the emerging adults' workers were collected individually, using the "snowball" method, based on the researchers' contacts.

Data analysis. The data were coded and included in the software SPSS Statistics, version 18. In this program, ANOVA for repeated measures was performed and the indicators needed for Sobel's test were calculated. For that calculation, the software Medgraph-PC (Jose, 2008) was used. Hayes' macro Process (version 2.01) was applied to calculate F values and the significance of each model (Hayes, 2013).

\section{Ethical Considerations}

Legal authorization for this study was obtained from the Ethics Committee at the University of Porto Faculty of Psychology and Educational Sciences. The participants received explanations about the general objective of the study and the response mode. In addition, they received information about the voluntary nature of their participation and the confidentiality and anonymity of their answers, in compliance with ethical principles for research involving human beings.

\section{Results}

\section{Differences Among Support Types}

To assess in which dimensions the young people score higher - help received from parents $(\mathrm{hr})$, help given to parents currently (hgc) or help they intend to give their parents in the future (hgf) - the ANOVA test for repeated 
measures was applied. The premises of the statistical procedure were assessed based on the kurtosis and skewness of distributions for the three dimensions under analysis and through Mauchly's sphericity test. A normal distribution was observed for all dimensions, as all asymmetry (sk) and kurtosis $(k u)$ coefficients figure between -1 and $+1: s k \mathrm{hr}=-1.05 ; k u \mathrm{hr}=.95 ; s k \mathrm{hgc}=-.47 ; k u \mathrm{hgc}=.66$; $s k$ hgf $=-.81 ; k u$ hgf $=.43$. A violation of the sphericity assumption was observed [Mauchly's $\mathrm{W}=.97 ; \chi^{2}(2)=6.70$; $p=.035]$. Therefore, Huynh-Feldt's epsilon was used as a correction factor, which revealed intergroup differences with a high effect dimension and test power $[F(2.475)=188.8$; $\eta^{2} p=.44$; test power $\left.=1\right]$ (Marôco, 2011).

The multiple comparison of means through Bonferroni's test showed that the emerging adults receive significantly $(p<.001)$ more support from their parents $(M=4.01 ; S D=0.78)$ than they are currently giving $(M=3.37 ; S D=0.78)$. They do intend to give more support in the future $(M=4.26$; $S D=0.65)$ than what they currently give $(p<.001)$ or receive $(p<.001)$. It seems evident, mainly considering most participants' age and occupation (students), that emerging adults need their parents' support in this phase of life and, although they do not seem to be in conditions yet to repay this support in the present, they feel grateful and intend to compensate their parents in the future.

To assess whether familism, filial maturity and satisfaction with the parental relationship mediate the effect of functional solidarity on the emerging adults' satisfaction with life, Sobel's test was applied. Simple mediation can be used to verify whether an independent variable affects a dependent variable through a potential mediating variable. Sobel's test is the most commonly used and recommended test to analyze the significance of simple mediation effects, particularly in larger samples. Therefore, through Sobel's test, it can be determined whether the relation between the independent and dependent variable was significantly reduced (partial mediation) or even annulled (total mediation) after the inclusion of a mediating variable. Hence, while a direct relation between the independent and dependent variable exists in the case of the partial mediation, beyond the indirect relation established through the mediating variable, in case of a total mediation effect, the significant direct relation between the independent and dependent variables will be annulled (Baron \& Kenny, 1986; Kenny, 2012; Preacher \& Hayes, 2008).

Sobel's test departs from the assumption of a normal distribution, as verified in this study, considering that, for all dimensions under analysis, skewness and kurtosis coefficients figure between -1 and +1 : familism $(S k=-.53$; $K u=.28)$, filial maturity $(S k=-.46 ; K u=.21)$, satisfaction with the relationship $(S k=-.91 ; K u=.41)$ and satisfaction with life $(S k=-.57 ; K u=.43)$. In Table 1 , the results for the test of the mediation effects are summarized.

Table 1

Mediation Effect of Familism, Filial Maturity and Satisfaction With Parents in the Relation Between Different Support Directions and Satisfaction With Life

\begin{tabular}{|c|c|c|c|c|c|}
\hline Predictor Support & Mediator & B & $F(2.240)$ & $\mathrm{R}^{2}$ & Sobel $Z$ \\
\hline \multirow[t]{4}{*}{ Received } & Direct effect & $.36^{* *}$ & & & \\
\hline & Familism & $.27^{* *}$ & $31.9^{* *}$ & .21 & $3.47^{* *}$ \\
\hline & Filial Maturity & $.19^{*}$ & $32.0^{* *}$ & .21 & $4.34^{* *}$ \\
\hline & Satisfaction parents & $.21^{* *}$ & $29.8^{* *}$ & .20 & $-0.40^{* *}$ \\
\hline \multirow[t]{4}{*}{ Given } & Direct effect & $.20^{*}$ & & & \\
\hline & Familism & .09 & $21.8^{* *}$ & .15 & $3.78^{* *}$ \\
\hline & Filial Maturity & .07 & $27.3^{* *}$ & .19 & $5.10^{* *}$ \\
\hline & Satisfaction parents & .07 & $24.1^{* *}$ & .17 & $4.25^{* *}$ \\
\hline \multirow[t]{4}{*}{ Discrepancy } & Direct effect & $-.23^{* *}$ & & & \\
\hline & Familism & $-.20^{*}$ & $27.1^{* *}$ & .18 & -1.28 \\
\hline & Filial Maturity & $-.15^{*}$ & $31.4^{* *}$ & .21 & $-2.76^{*}$ \\
\hline & Satisfaction parents & $-.13^{*}$ & $26.1^{* *}$ & .18 & $-3.57^{* *}$ \\
\hline
\end{tabular}

${ }^{*} p \leq .01 .{ }^{* *} p \leq .001$.

\section{Familism}

The cultural values of familism partially mediate the relation between the support received from the parents currently and satisfaction with life, as the direct effect of the support received on satisfaction with life drops when it is mediated by familism. This model explained $21 \%$ of the variance. When the mediation effect on the impact of the current support given on satisfaction with life is analyzed, the mediation obtained explains $15 \%$ of the variance: in this case, a total mediation effect can be observed, as the direct effect on satisfaction with life drops to.09 and loses significance when mediated by familism. The data suggest that both receiving and giving support in the family context contributes towards adherence to familism values, which subsequently enhance satisfaction with life. Nevertheless, no mediation whatsoever of this variable on the impact of the discrepancy on satisfaction with life was observed. The discrepancy in this study corresponds to the absolute difference between the current support received by the parents 
and the support the young people anticipate they will grant their parents in the future, ranging between 0 and .53 .

\section{Filial Maturity}

For the mediating effect of filial maturity, models were obtained with similar patterns to those described earlier. Thus, a partial mediating effect was observed for the impact of the received support on satisfaction with life, explaining $21 \%$ of the variance.

When the independent variable is the current support the emerging adults grant to their parents, a total mediation effect was observed, which explained $19 \%$ of the variance: the inclusion of filial maturity as a mediating variable effectively annulled the effect of the support variable on satisfaction with life. Finally, when the independent variable is the discrepancy between the support currently received and the support the participants intend to grant in the future, it is observed that a greater discrepancy is associated with lesser filial maturity $(-.19 ; p=.01)$ and lesser satisfaction with life $(-.23 ; p<.001)$. The latter effect is reduced when the mediation of filial maturity is introduced, explaining $21 \%$ of the variance. This result seems to suggest that the perception of more balanced exchanges contributes to psychological development and wellbeing or, alternatively, that filial maturity contributes to mitigate the negative effect of the discrepancy on well being.

\section{Satisfaction With Relantionship}

A partial mediation of the satisfaction with the relationship with both parents was obtained for the effect of the support received (explaining $20 \%$ of variance), and a full mediation for the effect of the support given on satisfaction with life (explaining 17\% of variance). Hence, the contemporary exchange of help, i.e. getting help from the parents and granting them help currently, influence the quality of the relation between parents and children, which positively influences the latter's satisfaction with life. Satisfaction in ter$\mathrm{ms}$ of the relation with both parents also mediates the effect of the discrepancy on satisfaction with life, explaining $18 \%$ of variance. A greater discrepancy seems to compromise satisfaction with the relationship with parents and also tends to cut down subjective wellbeing.

\section{Discussion}

Intergenerational solidarity whether in the strict family context or in the broader societal context seems to be increasingly interesting nowadays (Bengtson \& Oyama, 2010; Lowenstein, 2010). Despite cultural particularities, exposure to economic and cultural transformations associated with globalization is expected to affect the risks and opportunities the new generation of young people and their families experience in different societies (Brandão et al., 2012; Jensen \& Arnett, 2012) and, consequently, intergenerational solidarity intentions and practices (Yarrow, 2009). This justifies the application of the intergenerational solidarity model, the most important paradigm in social gerontology in the last three decades, to the study of the relationships between parents and emerging adults' children.

Intergenerational solidarity research has demonstrated that there are two main types of motivation to help among family members from different generations: altruism and reciprocity. Altruistic behaviors, attitudes and values are mainly motivated by the need of those who receive help, while reciprocal ones are mainly motivated by the return of previously received help. Hence, as long as they do not start working, the children tend to receive more help from their parents, mainly in financial terms, but often also in residential and functional terms (Andrade, 2010; Mendonça \& Fontaine, 2013a). Nevertheless, a greater balance between these exchanges is expected in the course of the lifecycle (Antonucci, 1985). Therefore, intergenerational help traditionally tends to flow more from older to younger generations, particularly from parents to children, until a relatively late phase in the lifecycle. When parents' health, autonomy and financial conditions decrease, an inversion of this flow is expected, turning the children into the parents' main help providers (Attias-Donfut, 2001; Fingerman et al., 2011; Lennartsson et al., 2010; Silverstein, Conroy, Wang, Giarrusso, \& Bengtson, 2002; Szydlik, 2008).

The empirical results also suggest that the intergenerational solidarity patterns vary according to social characteristics though. In countries with frequent upward social mobility among younger generations, the flow from children to parents can be earlier and more intense, as a sign of gratitude or repayment for the parents' investment in their children's education. In more developed countries, then, the continuation of the flow from parents to children until a later phase is frequent, because the elderly parents tend to "compensate" their adult children for the help they provide, and also because the younger generation does have less resources than the older one (Chauvel, 2006; Lennartsson et al., 2010). Intergenerational solidarity patterns depend on other, often associated factors, like on the availability of public social support structures and prevailing values related to public welfare states and family welfare states (Da Roit, 2007; Haberkern \& Szydlik, 2010).

Portugal seems to be a "family welfare" country, in which the obligations perceived with regard to family members are very strong: the family is expected to be the privileged source of support for its most vulnerable members, due to the predominant values and/or the lack of and costs associated with public/state or private services (Fontaine et al., 2006; Guerreiro \& Abrantes, 2004). The care systems societies adopt seem to be consistent with cultural preferences and values, with reciprocal influence (Haberkern \& Szydlik, 2010). From one generation to the other, however, these values and living conditions are also expected to change, often more rapidly than the available public and private support services. In the context of current societies, 
however, in which the distribution and expectations of roles between genders and generations is more diffuse, it can even be argued that the decision making underlying a modern solidarity is more anomic and depends on individual desires (Hammarstrom, 2005). It also seems to be undeniable that, in an economic crisis context, family support is increasingly fundamental for the survival and wellbeing of its most vulnerable members: the older generation and the younger generation. In this context, it seems important to perceive which variables seem to play an important role in the impact of solidary behaviors on subjective wellbeing among young people who are getting prepared for the transition to adult life.

As expected, the process through which functional solidarity influences the emerging adults' satisfaction with life is mediated by cultural values, psychological development and the quality of the relationship between parents and children (Aquilino, 2006). Although functional solidarity positively affects wellbeing, the role played by emerging adults seems to influence this process. When the emerging adults are the support providers, the gratifying effect on satisfaction with life seems to be more filtered by the values, maturity level and quality of the relationship with both parents. The results suggest that the emerging adults who consider that the family should prevail, who consider their parents as people with their own history and needs and who are satisfied with their relation are in better conditions to experience wellbeing and joy as a result of the support they grant to their parents. These variables act as productive mechanisms through which the support granted influences the satisfaction with life. Nevertheless, the mediation variables seem to exert a less strong role (partial mediation) when the emerging adults are the help receivers. These distinguished patterns for both functional solidary directions - giving and receiving - seem to demonstrate that getting help during emerging adulthood, at least in the current Portuguese context, is perceived as something normative and unquestionable. The increasing number of Portuguese young people in higher education (strongly represented in the sample), as a strategy to cope with a hard and precarious job market, can help to understand these results (Andrade, 2010; Brandão et al., 2012). In addition, in this phase of life, their parents may not need much help from them. Alternatively, these results could also indicate the emergence of a more self-focused and individualistic generation, which at bottom could compromise and break the generational contract, in public terms as well as in more private terms, within the family context (Arnett, 2004, 2007; Twenge, 2006).

A hypothetic non-compliance of the generational contract could derive more from the changes in actual living conditions (Chauvel, 2006) than from a change in the attitudes and psychological development characteristics, or particularly in the values. When considering the discrepancy between the support the emerging adults receive and the support they intend to give to their parents in the future, one can perceive that this "solidarity bank" (Antonucci, 1985) also influences the satisfaction with life. It is interesting that emerging adults intend to grant more help in the future than what they receive in the present. This result can obviously reflect an unrealistic intention and optimistic characteristic of this age range and/or generation (Arnett, 2004; Twenge, 2006). It may also suggest the prevalence of strong family bonds in Portugal though, even in younger generations. An alternative explanation could be the information source for this study: emerging adults. Literature on the intergenerational relations between parents and adult children has evidenced that parents attempt to transmit a more positive impression of the relationship with their children. With a view to maintaining a feeling of generational continuity, they tend to overestimate the contact maintained and the support given (generational stake) (Shapiro, 2004). According to Mandemakers and Dykstra's results (2008), however, the informants, whether parents or children, always tend to underestimate the help received and to overestimate the help granted. Anyway, an unbalanced resource exchange seems to reduce satisfaction with life, as well as filial maturity and satisfaction with the relationship. No relation whatsoever with familism was found though. Therefore, the emerging adults' values do not mediate its impact on satisfaction with life.

\section{Final Considerations}

The intent in this study was to contribute towards a better understanding of intergenerational family solidary in an age group about which little research has been done. It could be observed that young people anticipate that they will be able to help their parents more in the future comparing to the one they receive or grant today. Also, the support received and granted are associated with higher rates of satisfaction with life, while the perceived discrepancy is related to lower rates. Beyond the effects of support on satisfaction with life, this study explored the mediating effect of three distinguished variables: one associated with values (familism), another with development (filial maturity) and the third with the relationship (quality). As verified, all of these variables equivalently act as mediators of the relation between support and satisfaction with life. Their mediation power is stronger for the support given than for the support received. In general, results suggest that social and economic changes do not put the "solidarity bank" at risk but that, due to the current characteristics of the transition to adult life, the emerging adults seem to consider themselves more as "natural" receivers than as "natural" givers of support within their family.

This study presents clear limitations though. Although attitudes and prospective intentions are good predictors of behavior, many essentially uncontrollable factors can influence the effective help these young people will grant their parents in the future. For the sake of an example, when the majority is not employed yet, it is difficult to anticipate how professional practice can permit - or not - economic stability, availability of time and energy or geographic proximity with regard to the parents. All of these factors have been described as important predictors of functional solidarity (Szydlik, 2008). Another clear limitation that should be weighted when reading these results is related to the fact that 
most participants are college students, single and still live with their parents. In future research, it is also important to consider other information sources, particularly these young people's parents, and to analyze the dyadic relations between both, not only in solidarity, bus also in the values, filial maturity and quality of the relationship (Mandemakers \& Dykstra, 2008). Finally, it would also be relevant to explore the moderating role of gender and socioeconomic level in solidarity behaviors, given its proven relevance. It is particularly evident that women remain mostly responsible for guaranteeing care within the family, for the parents as well as for the children. As this phenomenon is still observed, despite the high rates of female participation in the job market (Arriagada, 2000; Coimbra et al., 2013), it is important to perceive whether this trend continues in the next generation.

\section{References}

Andrade, C. (2010). Transição para a idade adulta: Das condições sociais às implicações psicológicas. Análise Psicológica, 28(2), 255-267.

Antonucci, T. C. (1985). Personal characteristics, social support, and social behavior. In R. H. Binstock \& E. Shanas (Eds.), Handbook of aging and the social sciences (pp. 94-128). New York, NY: Van Nostrand Reinhold.

Aquilino, W. S. (2006). Family relationships and support systems in emerging adulthood. In J. J. Arnett \& J. L. Tanner (Eds.), Emerging adults in America: Coming of age in the $21^{\text {st }}$ century (pp. 193-218). Washington, DC: American Psychological Association.

Arnett, J. J. (2004). Emerging adulthood: The winding road from the late teens through the twenties. New York, NY: Oxford University Press.

Arnett,J.J.(2007). Suffering, selfish, slackers? Myths andreality about emerging adults. Journal of Youth and Adolescence, 36(1), 23-29. doi:10.1007/s10964-006-9157-z

Arriagada, I. (2000). Nuevas familias para un nuevo siglo? Paidéia (Ribeirão Preto), 10(18), 28-39. doi:10.1590/S0103-863X2000000100003

Attias-Donfut, C. (2001). The dynamics of elderly support: The transmission of solidarity patterns between generations. Zeitschrift für Gerontologie und Geriatrie, 34(1), 9-15.

Baron, R. M., \& Kenny, D.A.(1986). The moderator-mediator variable distinction in social psychological research: Conceptual, strategic, and statistical considerations. Journal of Personality and Social Psychology, 51(6), 1173-1182. doi:10.1037/0022-3514.51.6.1173

Bengtson, V. L., \& Oyama, P. S. (2010). Intergenerational solidarity and conflict: What does it mean and what are the big issues? In M. A. Cruz-Saco \& S. Zelenev (Eds.), Intergenerational solidarity: Strengthening economic and social ties (pp. 35-52). New York, NY: Palgrave Macmillan.

Bengtson, V. L., \& Roberts, R. E. L. (1991). Intergenerational solidarity in aging families: An example of formal theory construction. Journal of Marriage and the Family, 53(4), 856-870. doi:10.2307/352993
Birditt, K. S., Fingerman, K. L., Lefkowitz, E. S., \& Dush, C. M. K. (2008). Parents perceived as peers: Filial maturity in adulthood. Journal of Adult Development, 15(1), 1-12. doi:10.1007/s10804-007-9019-2

Brandão, T., Saraiva, L., \& Matos, P. M. (2012). O prolongamento da transição para a idade adulta e o conceito de adultez emergente: Especificidades do contexto português e brasileiro. Análise Psicológica, 30(3), 301-313.

Brody, E. M. (1985). Parent care as a normative family stress. The Gerontologist, 25(1), 19-29. doi:10.1093/geront/25.1.19

Chauvel L. (2006). Les nouvelles générations devant la panne prolongée de l'ascenseur social. Revue de l'OFCE, 96(1), 35-50. Retrieved from http://www. louischauvel.org/ofceralentissementgenerationnel5.pdf

Coimbra, S., Ribeiro, L., \& Fontaine, A. M. (2013). Intergenerational solidarity in an ageing western society: Sociodemographic determinants of intergenerational support to elderly parents. In I. Albert \& D. Ferring (Eds.), Intergenerational relations: European perspectives on family and society (pp. 205-222). Bristol, England: The Policy Press.

Da Roit, B. (2007). Changing intergenerational solidarities within families in a Mediterranean Welfare State: Elderly care in Italy. Current Sociology, 55(2), 251-269. doi: $10.1177 / 0011392107073306$

Diener, E., Emmons, R.A., Larsen, R. J., \& Griffin, S. (1985). The satisfaction with life scale. Journal of Personality Assessment, 49(1), 71-75. doi:10.1207/s15327752jpa4901_13

Fingerman, K. L., Pitzer, L. M., Chan, W., Birditt, K., Franks, M. M., \& Zarit, S. (2010). Who gets what and why? Help middle-aged adults provide to parents and grown children. The Journals of Gerontology Series B: Psychological Sciences and Social Sciences, 66B(1), 87-98. doi:10.1093/geronb/gbq009

Fontaine, A. M., Andrade, C., Matias, M., Gato, J., \& Mendonça, M. (2006). Valeurs des jeunes couples à double emploi. Revue Internationale de l'Éducation Familiale, 19(1), 31-51.

Fontaine, A. M., \& Matias, M. (2003). Familismo/ individualismo em jovens adultos: Construção de um instrumento e estudos exploratórios. Revista GalegoPortuguesa de Psicoloxía e Educacion, 10(8), 2348-2362.

Furman, W., \& Buhrmester, D. (1985). Children's perceptions of the personal relationships in their social networks. Developmental Psychology, 21(6), 10161024. doi:10.1037/0012-1649.21.6.1016

Gentile, B., Twenge, J. M., \& Campbell, W. K. (2010). Birth cohort differences in self-esteem, 1988- 2008: A crosstemporal meta-analysis. Review of General Psychology, 14(3), 261-268. doi:10.1037/a0019919

Grundy, E., \& Henretta, J. C. (2006). Between elderly parents and adult children: Anew look at the intergenerational care provided by sandwich generation. Ageing and Society, 26(5), 707-722. doi:10.1017/S0144686X06004934 
Guerreiro,M.D.,\&Abrantes,P.(2004). Moving intoadulthood in a Southern European country: Transitions in Portugal. Portuguese Journal of Social Science, 3(3), 191-209. doi:10.1386/pjss.3.3.191/1

Haberkern, K., \& Szydlik, M. (2010). State care provision, societal opinion and children's care of older parents in 11 European countries. Ageing \& Society, 30(2), 299-323. doi:10.1017/S0144686X09990316

Hayes, A. F. (2013). Introduction to mediation, moderation, and conditional process analysis: A regression-based approach. New York, NY: Guilford.

Hogerbrugge, M. J. A., \& Komter, A. E. (2012). Solidarity and ambivalence: Comparing two perspectives on intergenerational relations using longitudinal panel data. The Journals of Gerontology, Series B: Psychological Sciences and Social Sciences, 67B(3), 372-383. doi:10.1093/geronb/gbr157

Hammarstrom, G. (2005). The construct of intergenerational solidarity in a lineage perspective: A discussion on underlying theoretical assumptions. Journal of Aging Studies, 19(1), 33-51. doi:10.1016/j.jaging.2004.03.009

Jensen, L. A., \& Arnett, J. J. (2012). Going global: New pathways for adolescents and emerging adults in a changing world. Journal of Social Issues, 68(3), 473-492. doi:10.1111/j.1540-4560.2012.01759.x

Jose, P. E. (2008, December). MedGraph-I: A programme to graphically depict mediation among three variables: The internet version. Version 2.0. Wellington, New Zealand: Victoria University of Wellington. Retrieved from $\mathrm{http}: / \mathrm{www}$. victoria.ac.nz/psyc/paul-jose-files/medgraph/medgraph.php

Katz, R. (2009). Intergenerational family relations and subjective well-being in old age: A cross-national study. European Journal of Ageing, 6(2), 70-90. doi:10.1007/s10433-009-0113-0

Kenny, D. A. (2012). Mediation. Recuperado de http:// davidakenny.net $/ \mathrm{cm} /$ mediate.htm

Lago, M. C. S., Souza, C. D., Kaszubowski, E., \& Soares, M. S. (2009). Gênero, gerações e espaço doméstico: Trabalho, casa e família. Paidéia (Ribeirão Preto), 19(44), 357-366. doi:10.1590/S0103-863X2009000300010

Lennartsson, C., Silverstein, M., \& Fritzell, J. (2010). Time-for-money exchanges between older and younger generations in Swedish families. Journal of Family Issues, 31(2), 189-210. doi:10.1177/0192513X09344158

Lowenstein, A. (2007). Solidarity-conflict and ambivalence: Testing two conceptual frameworks and their impact on quality of life for older family members. The Journals of Gerontology: Series B: Psychological Sciences and Social Sciences, 62B(2),S100-S107.doi:10.1093/geronb/62.2.S100

Lowenstein, A. (2010). Determinants of the complex interchange among generations: Collaboration and conflict. In M. A. Cruz-Saco \& S. Zelenev (Eds.), Intergenerational Solidarity: Strengthening economic and social ties (pp. 53-82). NY: Palgrave Macmillan.
Mandemakers, J. J., \& Dykstra, P. A. (2008). Discrepancies in parent's and adult child's reports of support and contact. Journal of Marriage and Family, 70(2), 495-506. doi:10.1111/j.1741-3737.2008.00496.x

Marcoen, A. A. (1995). Filial maturity of middle-aged adult children in the context of parent care: Model and measures. Journal of Adult Development, 2(2), 125-136.

Marôco, J. (2011). Análise estatística com SPSS statistics (5a ed.). Pero Pinheiro, Portugal: Report Number.

Mendonça, M., \& Fontaine, A. M. (2013a). Late nest leaving in Portugal: Its effects on individuation and parent-child relationships. Emerging Adulthood. doi:10.1177/2167696813481773

Mendonça, M., \& Fontaine, A. M. (2013b). Filial maturity in young adult children: The validity of the Filial Maturity Measure and the role of adult transitions. TPM: Testing, Psychometrics, Methodology in Applied Psychology, 20(1), 27-45.

Merz, E.-M., Schulze, H.-J., \& Schuengel, C. (2010). Consequences of filial support for two generations:A narrative and quantitative review. Journal of Family Issues, 31(11), 1530-1554. doi:10.1177/0192513X10365116

Monteiro,I.B.J.(2010). Solidariedadefamiliarintergeracional e bem-estar psicológico: Estudo intergeracional sobre a relação de apoio entre filhas adultas e suas mães (Unpublished Master's Thesis). Universidade do Porto, Porto, Portugal.

Neto, F., Barros, J., \& Barros, A. (1990). Satisfação com a vida. In L. Almeida, R. Santiago, P. Silva, L. Oliveira, \& O. Caetano (Eds.). A acção educativa: Análise psicossocial (pp. 105-117). Leiria, Portugal: ESEL/APPORT.

Oliveira, M. R. S. (2011). Geração sanduiche: Análise da solidariedade para com os seus pais idosos e filhos na fase de adultez emergente. (Unpublished Master's Thesis). Universidade do Porto, Porto, Portugal.

Preacher, K. J., \& Hayes, A. F. (2008). Asymptotic and resampling strategies for assessing and comparing indirect effects in multiple mediator models. Behavior Research Methods, 40(3), 879-891. doi:10.3758/BRM.40.3.879

Rezende, V. L., Derchain, S., Botega, N. J., Sarian, L. O., Vial, D. L., Morais, S. S., \& Perducaris, A. A. M. (2010). Avaliação psicológica dos cuidadores de mulheres com câncer pelo General Comfort Questionnaire. Paidéia (Ribeirão Preto), 20(46), 229-237. doi:10.1590/S0103-863X2010000200010

Scabini, E., Marta, E., \& Lanz, M. (2006). The transition to adulthood and family relations: An intergenerational perspective. New York, NY: Psychology Press.

Schwarz, B., Albert, I., Trommsdorff, G., Zheng, G., Shi, S., \& Nelwan, P. R. (2010). Intergenerational support and life satisfaction: A comparison of Chinese, Indonesian, and German elderly mothers. Journal of Cross-Cultural Psychology, 41(5-6), 706-722. doi:10.1177/0022022110372197 
Shapiro, A. (2004). Revisiting the generation gap: Exploring the relationships of parent/adult-child dyads. International Journal of Aging \& Human Development, 58(2), 127-146. doi:10.2190/EVFK-7F2X-KQNV-DH58

Silverstein,M.,\&Bengtson, V.L.(1994).Doesintergenerational social support influence the psychological well-being of older parents? The contingencies of declining health and widowhood. Social Science and Medicine, 38(7), 943-957. doi:10.1016/0277-9536(94)90427-8

Silverstein, M., Chen, X., \& Heller, K. (1996). Too much of a good thing? Intergenerational social support and the psychological well-being of aging parents. Journal of Marriage and the Family, 58(4), 970-982.

Silverstein, M., Conroy, S. J., Wang, H., Giarrusso, R., \& Bengtson, V. L. (2002). Reciprocity in parent-child relations over the adult life course. The Journals of Gerontology: Series B: Psychological Sciences and Social Sciences, 57B(1), S3-S13. doi:10.1093/geronb/57.1.S3

Szydlik, M. (2008). Intergenerational solidarity and conflict. Journal of Comparative Family Studies, 39(1), 97-114.

Twenge, J. M. (2006). Generation me: Why today's young Americans are more confident, assertive, entitled-and more miserable than ever before. New York, NY: Free Press.

Twenge, J. M., \& Campbell, W. K. (2009). The narcissism epidemic: Living in the age of entitlement. New York, NY: Atria.

Twenge, J. M., Campbell, W. K., \& Freeman, E. C. (2012). Generational differences in young adults' life goals, concern for others, and civic orientation, 1966-2009. Journal of Personality and Social Psychology, 102(5), 1045-1062. doi:10.1037/a0027408

Yarrow, A. L. (2009). Sustainability and intergenerational solidarity. Generations: Journal of the American Society on Aging, 33(3), 103-104.

Susana Coimbra is a psychologist and Ph.D. in Psychology from Universidade do Porto. Assistant professor, Faculty of Psychology and Educational Sciences, Universidade do Porto.

Marina Goulart Mendonça is a Ph.D. candidate in Psychology at Universidade do Porto. Associate Researcher, Research Institute for Social Sciences, Keele University.

Received: $10^{\text {th }}$ Oct. 2012

$1^{\text {st }}$ Revision: $4^{\text {th }}$ Apr. 2013

$2^{\text {nd }}$ Revision: $3^{\text {rd }}$ May 2013

Approved: 30 $0^{\text {th }}$ May 2013

How to cite this article:

Coimbra, S., \& Mendonça, M. G. (2013). Intergenerational solidarity and satisfaction with life: Mediation effects with emerging adults. Paidéia (Ribeirão Preto), 23(55), 161-169. doi:10.1590/1982-43272355201303 


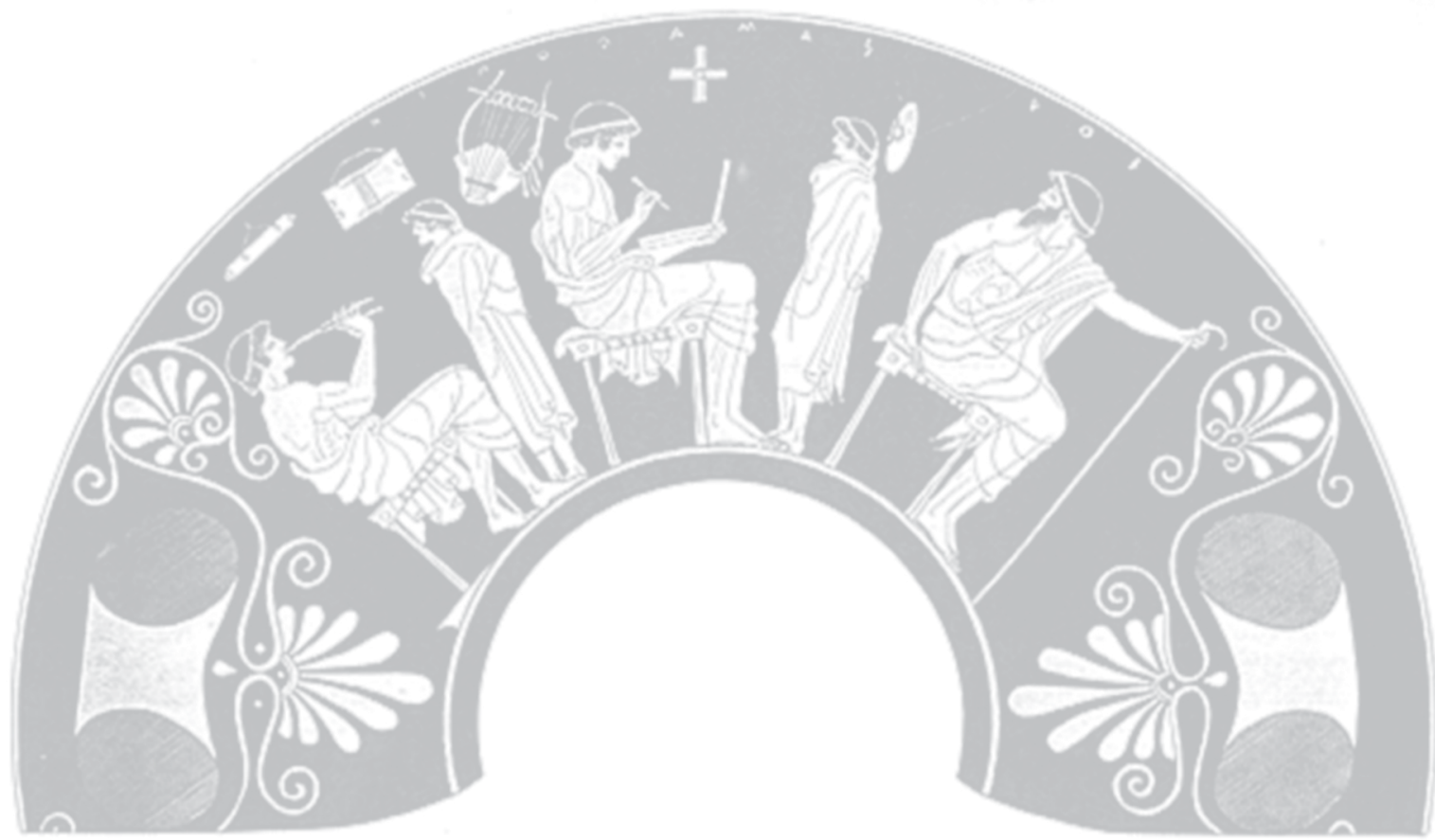

